\title{
Monthly variation in the diet of harbour seals in inshore waters along the southeast Shetland (UK) coastline
}

\author{
Edward G. Brown ${ }^{1, *}$, Graham J. Pierce ${ }^{2}$ \\ 19 Twageos Road, Lerwick, Shetland ZE1 0BB, United Kingdom \\ ${ }^{2}$ University of Aberdeen, Department of Zoology, Tillydrone Avenue, Aberdeen AB24 2TZ, United Kingdom
}

\begin{abstract}
We studied the diets of harbour seals Phoca vitulina along the southeast Shetland (UK) coastline by analysing prey remains found in faeces $(N=733)$ at haul-out sites. A total of 44325 fish otoliths were recovered. Sandeel (Ammodytidae) otoliths were the most numerous (38704), followed by Gadidae (4707). Otoliths were measured and experimentally derived digestion coefficients were applied (correcting for digestion in the seal's gut) to estimate the size of ingested prey fishes. Gadids accounted for an estimated $53.4 \%$ of the annual diet by weight, sandeels $28.5 \%$ and pelagic fishes $13.8 \%$. The dominant gadid fishes were whiting Merlangius merlangus (25.3\%) and saithe Pollachius virens $(11.1 \%)$. The range of species observed in the diet was similar to that recorded in other areas of the UK One exception to this was garfish Belone belone accounting for $34.1 \%$ of the diet in September (1996), which is a species not previously reported for harbour seal diets in UK waters. There were stuuny seasonai patterns in the contribution of sandeels and gadids, with sandeels being important in spring and early summer, and gadids in winter. Pelagic species (mainly herring Clupea harengus, garfish and mackerel Scomber scombrus) were important in late summer and autumn. Observed seasonal patterns are similar to those previously recorded for harbour seal diets in the Moray Firth area of Scotland and appear to coincide with changes in prey availability. A comparison of the utility of using only otoliths to estimate seal diet with all identifiable structures showed that using otoliths alone underestimated the contribution of pelagic fish and overestimated the importance of gadids and sandeels.
\end{abstract}

KEY WORDS: Harbour seal · Phoca vitulina - Otoliths $\cdot$ Shetland · Diet - Seasonal variation

\section{INTRODUCTION}

Harbour seals or common seals Phoca vitulina have been extensively studied in UK waters. Many of these studies, particularly those on diet and feeding ecology, have focused on interactions with fisheries. Diets of harbour seals in UK waters have been described in Norfolk (Sergeant 1951), the northeast coast of Scotland (Rae 1960, 1968, 1973), the Moray Firth (Pierce et al. 1990, Pierce et al. 1991a, b, Tollit \& Thompson 1996), Orkney (Pierce et al. 1990) and the west coast of Scotland (Boyle 1990). Only in the Moray Firth has seasonal and interannual variation in diet been described in detail. Changes in diet are generally assumed to

-E-mail: e.brown@zetnet.co.uk relate to changes in prey availability, as also suggested by Härkönen (1987) for this species in the Kattegat and Skagerrak.

The only previous work on harbour seal diets around the Shetland Islands, UK $\left(60^{\circ} \mathrm{N}, 1\right.$ to $2^{\circ} \mathrm{W}$; Fig. 1$)$, documented the diet of harbour seals on the island of Mousa during the third quarter of 1994 (Brown \& Pierce 1997). This work indicated that harbour seals preyed on a wide range of species, including most of the target species in local fisheries. There are around 6200 harbour seals present in the waters around the Shetland Islands (Hiby et al. 1996), representing over $20 \%$ of the UK population. The minimum population in UK waters is around 28720 seals (Hiby et al. 1996). Numbers have increased substantially since protective legislation was introduced in the early 1970 s. 
Shetland is thus an appropriate site for a new study of seasonal variation in diet of harbour seals. Such a study is also of interest to improve knowledge of interactions between harbour seals and commercial fisheries around Shetland. The southeast coast of Shetland was chosen as the focus of the present study because haul-out sites along this part of the coast are used by harbour seals all year round and are readily accessible for sampling. This stretch of coast accounts for approximately $20 \%$ of the total Shetland population of harbour seals (Duck et al. 1993)

Competition between seals and fisheries is particularly topical at a time when the total allowable catches for many commercial fish species are being reduced, and is a subject that has been extensively reviewed in the UK and elsewhere (e g. Gulland 1987, Harwood 1987, 1992, des Clers \& Prime 1996). The Shetland Islands are situated in the centre of some of the most productive fishing grounds in the North Sea. Fishing is one of the main traditional industries in the Islands, employing approximately 1870 persons in catching, processing and ancillary industries (Anon 1996a). Over $135000 \mathrm{t}$ of fish were landed into Shetland during 1995, worth E28.3 million at first sale (Anon 1996b).

In UK waters, grey seals Halichoerus grypus are generally perceived as a greater threat to fisheries, partly because of their greater numbers (an estimated all-age UK population of 108500 seals in 1994: Hiby et al. 1996). However, in Shetland, harbour seals are more numerous than grey seals. It is estimated that there are around 3500 grey seals associated with breeding sites around the Shetland Islands, a figure which has remained relatively static since the 1970 s (Brown 1995). Telemetry studies indicate that harbour seals generally forage in inshore waters (Thompson \& Miller 1990, Thompson 1993). Given the value of inshore grounds to the local fishing fleet in Shetland, harbour seals may have greater direct impact on local fisheries than grey seals, which may travel considerable distances out to sea to forage (McConnell et al. 1992, SMRU 1994).

In recent years identifying and measuring fish otoliths recovered from faeces has been the main method of assessing the diets of seals from around the British Isles. Using this method to determine the diets of predators is subject to several important sources of error. Otoliths are eroded as they pass through the gut of seals (da Silva \& Neilson 1985, Dellinger \& Trillmich 1988. Harvey 1989), which can result in underestimation of the size of prey fish consumed (da Silva \& Neilson 1985, Jobling 1987, Harvey \& Antonelis 1994). Captive feeding experiments have been used to estimate 'digestion coefficients' to account for size reduction in otoliths (e.g. Tollit et al. 1997). Other problems with the methodology are that some species may be completely absent or under-represented when the diet is assessed from otoliths alone, such as those with no otoliths (e.g. Rajidae), with small or fragile otoliths, or the heads of which are discarded by seals during feeding (Boyle et al. 1990, Pierce et al. 1991a). Nevertheless, analysis of faeces probably represents the single best method available to assess the diet of seals around the British Isles (Prime \& Hammond 1990).

The aims of this study were: (1) to examine monthly variation in harbour seal diets along the southeast coastline of Shetland; (2) to relate changes in diet composition to known changes in prey availability; (3) to assess the utility of using other hard remains in addition to otoliths to detect prey species present in the samples and to improve quantitative estimates of diet composition, and (4) to identify potential competition between seals and local fisheries.

\section{METHODS}

Sample collection. Regular visits were made to 8 harbour seal haul-outs along the southeast Shetland coastline (Fig. 1) over the period 1 May 1995 to 30 April 1996. The numbers and species of seals at haul-out sites were noted before collection began. In some instances grey seals were present at sites but spatial separation between the species was the norm with grey seals preferring to lie close to the water's edge or on tidal rocks offshore. Areas which grey seals used were avoided when searching for faecal material and the numbers of grey seals that were actually intermixed with the harbour seals never exceeded $10 \%$ of the total number of all seals present. Each faecal sample was collected into a separate, light duty polythene bag and frozen at $-20^{\circ} \mathrm{C}$ until further processing.

Processing and identification of prey remains. Faecal samples were washed through a series of sieves (2.00 and $0.355 \mathrm{~mm}$ ); all hard parts (fish otoliths, cephalopod beaks and fish bones) were extracted from the sieves, and stored in alcohol until further processing. Samples were later sorted, otoliths were dried and stored in small glass vials, and cephalopod beaks and fish bones were stored in Industrial Methylated Spirits.

Otoliths were identified to the lowest possible taxon, usually to species, using a reference collection of local fish and a guidebook (Härkönen 1986). It was not always possible to identify them to species due to morphological similarities, particularly for small or badly digested otoliths. Thus haddock Melanogrammus aeglefinus, saithe Pollachius virens and pollack Pollachius pollachius could not always be distinguished from each other; similarly Norway pout Trisopterus esmarki and poor cod Trisopterus minutus were sometimes recorded as Trisopterus spp. It was not possible 


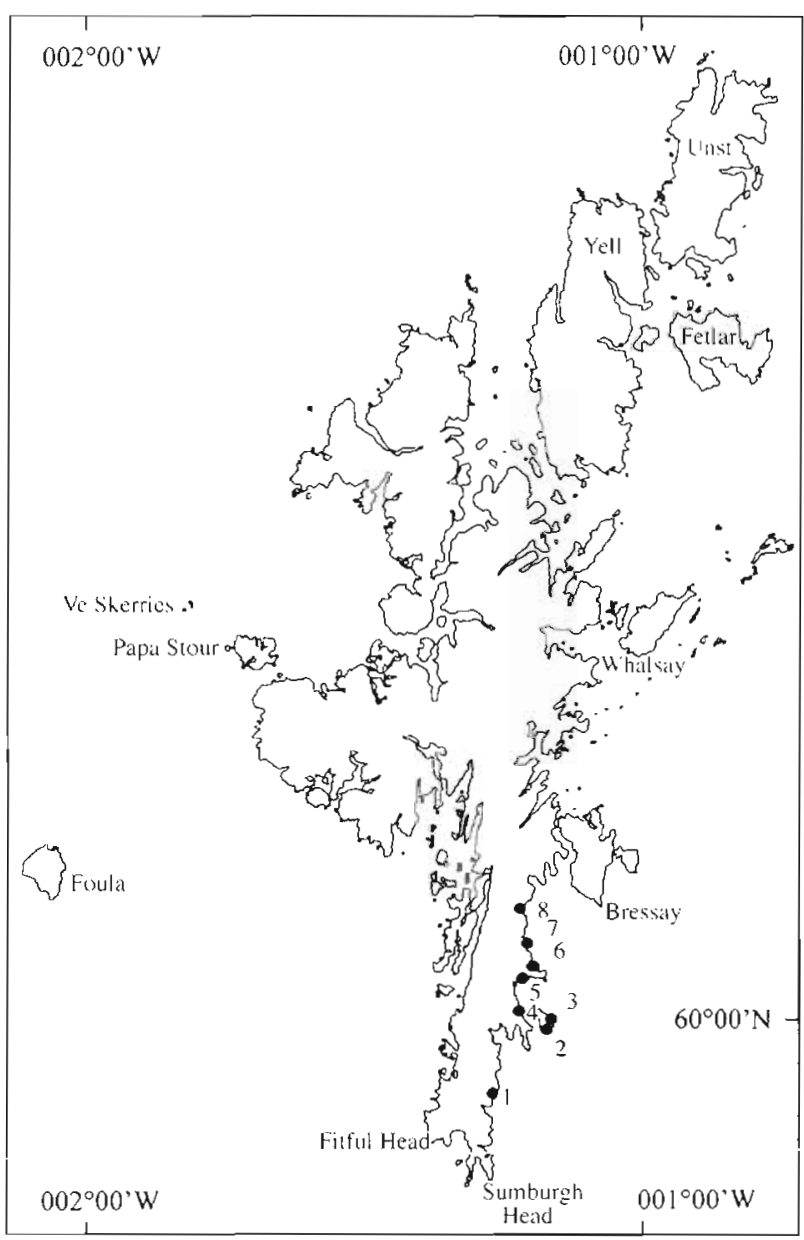

Fig. 1. Shetland Islands; locations of collection sites are indicated on map: (1) Trosswick Ness; (2) Mousa West Pooli (3) Mousa East Pool; (4) Leebitton; (5) Aiths Voe; (6) Alths Wick; (7) Orkraquoy; (8) Quarff

to distinguish between the 5 species of sandeels found in Shetland waters and all sandeel otoliths were therefore recorded as sandeel (Ammodytidae). Cephalopod beaks were identified by M. B. Santos (University of Aberdeen).

Estimating prey size. To estimate original prey sizes, otoliths and beaks were measured using a binocular dissecting microscope fitted with an eyepiece graticule. Normally otoliths were measured lengthways. However, for species of fish such as herring Clupea harengus and whiting Merlangius merlangus (whose otoliths were almost always broken lengthways) otolith width was measured.

Experimentally derived digestion coefficients (Tollit et al. 1997) were applied to measurements on otoliths to account for digestive erosion. Tollit et al. (1997) distinguished a series of grades of digestion, based on changes in morphological features of the otoliths, as assessed by visual examination. Grade-specific correc- tion factors are available for cod Gadus morhua, whiting and sandeels. We used the correction factor that best matched the degree to which our otoliths were eroded, e.g. for cod otoliths we selected the 'low' correction factor (1.07), for sandeels we selected the 'low' correction factor (1.16) and for whiting we selected the 'medium' correction factor (1.365). Tollit et al. (1997) also calculated species-specific coefficients for lemon sole Microstomus kitt and herring. For all other fish species, Tollit et al.'s average coefficients of 1.25 for otolith length and 1.24 for otolith width were used. All digestion coefficients used are given in Appendix 1.

Fish lengths and weights were estimated using regressions given in Appendix 1. Where possible, data for otolith size-fish size relationships are collected from fish caught in Shetland waters (E. G. Brown unpubl. data). Each otolith was assumed to represent 0.5 fish. Cephalopod weights were estimated using regressions from a published guide (Clarke 1986) and from unpublished data (G. J. Pierce \& M. B. Santos). The total weight represented by each prey category was thus derived for each month and expressed as a percentage of the total for all categories. For each month, the mean number of otoliths per faex (excluding the samples not containing any otoliths) was also calculated for the main prey species and groups.

Analysis of otolith size. For the purpose of carrying out a statistical comparison on the sizes of fish consumed we compared otolith size, since both the weight and length of the fish were estimated from the otolith. We feel that comparing the size of the otoliths directly is a more reliable method than comparing estimated fish lengths, as these are subject to additional error. Only for cod were fish lengths compared (several measurements on cod otoliths were made on broken otoliths and width had to be measured, in effect reducing the sample size available for comparison). For each of the main prey categories (sandeel, cod, haddock, herring, saithe, ling Molva molva, herring, Norway pout, poor cod, whiting), data were grouped by season (quarters of the year). Data for each quarter and the whole year were tested for normality using the Anderson-Darling test (Minitab software). For all species there were significant departures from normality, due to skewed or polymodal distributions. Comparisons between quarters were therefore made using the nonparametric Kruskal-Wallis 1-way analysis of variance. Post-hoc comparisons between each pair of seasons were made using the Mann-Whitney $U$-test. Since, for each species, there were 6 possible comparisons between seasons, a Bonferroni correction was applied to the probability level accepted for significance (we thus used $\mathrm{p}<0.0083$ )

For sandeel, whiting and ling there were sufficient data to analyse monthly differences. The same proce- 
dures were used, although with 66 possible intermonthly comparisons, $p<0.00076$ is required for significance

Analysis of numbers of otoliths per faex. For each of the main prey categories (sandeel, cod, haddock, herring, garfish Belone belone, saithe, ling, Trisopterus, whiting, all gadid species and for all species combined), data on numbers of otoliths per faex (excluding faeces containing no otoliths of any species) were grouped by season (quarters of the year). Data for each quarter and the whole year were tested for normality using the Anderson-Darling test (Minitab software). For all species there were significant departures from normality, due to highly right-skewed distributions (zero otoliths was the most frequent class). Comparisons between months were therefore made using the non-parametric Kruskal-Wallis 1-way analysis of variance. Post-hoc comparisons between each pair of seasons were made using the Mann-Whitney $U$-test, with a Bonferroni correction as in the analysis of otolith size.

Errors associated with basing diet estimates on otoliths. To assess whether our use of otoliths to determine the diet of harbour seals was valid, we also identified other fish bones present in the faecal samples, using an extensive reference collection at the University of Aberdeen and a guide (Watt et al. 1997). Pierce et al. (1991a) demonstrated the usefulness of certain diagnostic fish bones in identifying fish prey consumed when otoliths were absent. Due to the similarity of the bones throughout the Gadidae, we could usually only classify to the family level. Fish bones were used in identification of herring (otic bullae, vertebrae and maxillae), Gadidae (pre-maxillae, maxillae, vertebrae, vomer and post temporals), Ammodytidae (atlas vertebrae and caudal vertebrae), flatfishes (vertebrae, premaxillae, maxillae and urohyals), garfish (vertebrae and pelvic girdle) and mackerel Scomber scombrus (vertebrae). For the terminology of fish bones see Watt et al. (1997). The utility of using otoliths alone was assessed by comparing the frequency of occurrence with which different prey categories were identified using (1) only otoliths and (2) all identifiable structures. Comparisons were made on raw frequencies using $\chi^{2}$ tests.
Comparison of diet and fisheries. Data and information on fisheries around the Shetland Islands were obtained from the Fisheries Research Services Marine Laboratory at Aberdeen and the Shetland office of the Scottish Fisheries Protection Agency.

\section{RESULTS}

\section{Collection of samples}

A total of 733 faecal samples was recovered from 127 visits to harbour seal haul-outs at Troswick Ness, Leebitton, Mousa West Pool, Mousa East Pool, Aiths Voe, Aiths Wick, Okraquoy and Quarff (Fig. 1). The percentage of sampling trips that were successful $(\geq 1$ faeces collected), and the number of samples collected, were highest in August and September, coinciding with the annual moult. Fewest samples were collected in October, November and February (Table 1). Overall, 628 faecal samples $(86 \%)$ were found to contain fish otoliths. The percentage of samples containing otoliths varied between months (Table 1 ).

\section{Numbers of otoliths recovered}

A total of 44325 fish otoliths was recovered from the faecal samples. Table 2 gives the numbers of otoliths recovered by month for the main categories of fish prey. Sandeel otoliths were numerically the most abundant with 38704 otoliths recovered $(87.3 \%$ of the total number found), followed by Gadidae with 4707 otoliths recovered $(10.6 \%)$, including Trisopterus spp. with 2793 otoliths (6.3\%) (Table 2). Flatfish otoliths were only found occasionally with a total of 33 recovered, of which lemon sole accounted for 16 .

The numbers of otoliths recovered per month ranged from 142 to 13137 . The number of sandeel otoliths recovered by month ranged from 19 to 10985 , while the number of Gadidae otoliths recovered ranged from 19 to 1703 .

Table 1. Numbers of site visits per month with \% of visits that were successful in collecting 1 . or more harbour seal Phoca vitulina scats and numbers of scats recovered per month, with \% containing fish otoliths

\begin{tabular}{|c|c|c|c|c|c|c|c|c|c|c|c|c|c|}
\hline & Jan & Feb & Mar & Apr & May & Jun & Jul & Aug & Sep & Oct & Nov & Dec & Totals \\
\hline No, of site visits & 14 & 6 & 17 & 7 & 15 & 10 & 6 & 8 & 5 & 14 & 16 & 9 & 127 \\
\hline$\%$ successful & $64 \%$ & $83 \%$ & $76 \%$ & $71 \%$ & $60 \%$ & $80 \%$ & $83 \%$ & $100 \%$ & $100 \%$ & $71 \%$ & $50 \%$ & $78 \%$ & $72 \%$ \\
\hline No. of scats found & 49 & 9 & 75 & 26 & 29 & 55 & 47 & 208 & 145 & 38 & 26 & 26 & 733 \\
\hline No. with otoliths & 47 & 9 & 64 & 17 & 28 & 49 & 44 & 188 & 111 & 30 & 17 & 24 & 628 \\
\hline$\%$ with otoliths & $96 \%$ & $100 \%$ & $86 \%$ & $65 \%$ & $97 \%$ & $89 \%$ & $94 \%$ & $90 \%$ & $77 \%$ & $79 \%$ & $65 \%$ & $92 \%$ & $86 \%$ \\
\hline
\end{tabular}




\section{Number of otoliths per faex}

The number of otoliths per faex for all species was generally lowest during autumn and winter and highest in spring (Table 2). Overall variation in the number of otoliths (all species combined) per faex in relation to season was significant (Kruskal-Wallis; $H=33.77, \mathrm{p}<$ $0.0005)$. Otoliths were more numerous in quarter 2 (Apr-Jun) (79.9 to 142 per faex) than in quarters 3 (Jul-Sep) (46.1 to 69.9) ( $<<0.00005)$ and 4 (Oct-Dec) (15.6 to 85.9) ( $p=0.0003)$. Otoliths were also more numerous in quarter 1 (Jan-Mar) (15.8 to 133 ) than in quarter $3(p=0.0081)$. Gadid otoliths were most common during winter and least common during spring and early summer (Table 2). Overall variation in the number of gadid otoliths per faex in relation to season was significant $(H=38.35, p<0.0005)$. Gadids were more numerous in quarters 1,3 and 4 than in quarter 2 ( $\mathrm{p}<0.00005$ in all cases). The number of whiting otoliths per faex was highest during the last quarter (1.82 to 11.8), and was lowest during the second quarter $(0.18$ to 0.76$)$. Overall variation in the number of whiting otoliths per faex relation to season was significant $(H=44.91, p<0.0005)$. Whiting were more numerous in quarter 4 than in quarters $1(p=0.0082), 2$ ( $\mathrm{p}<0.00005)$ and $3(\mathrm{p}=0.0037)$. Whiting were also more numerous in quarters 1 and 3 than in quarter 2 ( $p=0.0027$ and $p=0.0005$ respectively). Saithe was most common during November and January (2.83 and 2.77 otoliths per faex respectively) and infrequently recorded during the summer months (0.02 to 0.95). Trisopterus spp. was most common during December to January (15.8 to 5.06). Overall variation in the number of Trisopterus otoliths per faex in relation to season was significant $(H=40.45, \mathrm{p}<0.0005)$. Trisopterus were more numerous in quarter 1 than in quarters 2,3 and $4(p<0.00005, p=0.0073$ and $p=0.0005$ respectively), and more numerous in quarter 3 than in quarter 2 ( $p<0.00005)$. Numbers of otoliths for pelagic fish species were highest during summer (1.32 to 2.39) and lowest during winter $(0.11$ to 0.71$)$. Herring was most common from June to August (1.32 to 2.37) and lowest during winter $(0.0$ to 0.12$)$. Overall variation in the number of herring otoliths per faex in relation to sea-

Table 2. Monthly variation in the numbers of fish otoliths recovered from harbour seal Phoca vitulina faeces, for the main prey species and group totals. Mean number of otoliths per faex for the main prey species and groups are given in parentheses

\begin{tabular}{|c|c|c|c|c|c|c|c|c|c|c|c|c|c|c|}
\hline Species & Jan & Feb & Mar & Apr & May & Jun & Jul & Aug & Sep & Oct & Nov & Dec & $\begin{array}{l}\text { Species } \\
\text { totals }\end{array}$ & $\begin{array}{l}\% \text { of } \\
\text { total }\end{array}$ \\
\hline Cod & $\begin{array}{c}1 \\
(0.02)\end{array}$ & $\begin{array}{c}0 \\
(0)\end{array}$ & $\begin{array}{c}8 \\
(0.13)\end{array}$ & $\begin{array}{c}1 \\
(0.06)\end{array}$ & $\begin{array}{c}0 \\
(0)\end{array}$ & $\begin{array}{c}1 \\
(0.02)\end{array}$ & $\begin{array}{c}2 \\
(0.05)\end{array}$ & $\begin{array}{c}33 \\
(0.18)\end{array}$ & $\begin{array}{c}3 \\
(0.03)\end{array}$ & $\begin{array}{c}2 \\
(0.07)\end{array}$ & $\begin{array}{c}3 \\
(0.18)\end{array}$ & $\begin{array}{c}1 \\
(0.04)\end{array}$ & $\begin{array}{c}55 \\
(0.09)\end{array}$ & 0.12 \\
\hline Haddock & $\begin{array}{c}1 \\
(0.02)\end{array}$ & $\begin{array}{c}1 \\
(11.1)\end{array}$ & $\begin{array}{c}5 \\
(0.08)\end{array}$ & $\begin{array}{c}1 . \\
(0.06)\end{array}$ & $\begin{array}{c}1 \\
(0.04)\end{array}$ & $\begin{array}{c}0 \\
(0)\end{array}$ & $\begin{array}{c}1 \\
(0.02)\end{array}$ & $\begin{array}{c}12 \\
(0.06)\end{array}$ & $\begin{array}{c}4 \\
(0.04)\end{array}$ & $\begin{array}{c}0 \\
(0)\end{array}$ & $\begin{array}{c}0 \\
(0)\end{array}$ & $\begin{array}{c}5 \\
(0.21)\end{array}$ & $\begin{array}{c}31 \\
(0.05)\end{array}$ & 0.07 \\
\hline Saithe & $\begin{array}{c}130 \\
(2.77)\end{array}$ & $\begin{array}{c}0 \\
(0)\end{array}$ & $\begin{array}{c}10 \\
(0.16)\end{array}$ & $\begin{array}{c}0 \\
(0)\end{array}$ & $\begin{array}{c}2 \\
(0.07)\end{array}$ & $\begin{array}{c}1 \\
(0.02\}\end{array}$ & $\begin{array}{c}42 \\
(0.95)\end{array}$ & $\begin{array}{c}29 \\
(0.15)\end{array}$ & $\begin{array}{c}28 \\
(0.25)\end{array}$ & $\begin{array}{c}9 \\
(0.30)\end{array}$ & $\begin{array}{c}9 \\
(0.53)\end{array}$ & $\begin{array}{c}68 \\
(2.83)\end{array}$ & $\begin{array}{c}328 \\
(0.52)\end{array}$ & 0.74 \\
\hline Whiting & $\begin{array}{c}53 \\
(1.13)\end{array}$ & $\begin{array}{c}10 \\
(1.11)\end{array}$ & $\begin{array}{c}82 \\
(1.28)\end{array}$ & $\begin{array}{c}13 \\
(0.76)\end{array}$ & $\begin{array}{c}5 \\
(0.18)\end{array}$ & $\begin{array}{c}20 \\
(0.41)\end{array}$ & $\begin{array}{c}105 \\
(2.39)\end{array}$ & $\begin{array}{c}322 \\
(1.71)\end{array}$ & $\begin{array}{c}134 \\
(1.12)\end{array}$ & $\begin{array}{c}353 \\
(11.8)\end{array}$ & $\begin{array}{c}31 \\
(1.82)\end{array}$ & $\begin{array}{c}86 \\
(3.58)\end{array}$ & $\begin{array}{c}1214 \\
(1.93)\end{array}$ & 2.74 \\
\hline Ling & $\begin{array}{c}10 \\
(0.21)\end{array}$ & $\begin{array}{c}1 \\
(0.11)\end{array}$ & $\begin{array}{c}7 \\
(0.11)\end{array}$ & $\begin{array}{c}1 \\
(0.06)\end{array}$ & $\begin{array}{c}4 \\
(0.14)\end{array}$ & $\begin{array}{c}8 \\
(0.16)\end{array}$ & $\begin{array}{c}1 \\
(0.02)\end{array}$ & $\begin{array}{c}12 \\
(0.06)\end{array}$ & $\begin{array}{c}9 \\
(0.08)\end{array}$ & $\begin{array}{c}4 \\
(0.13)\end{array}$ & $\begin{array}{c}1 \\
(0.06)\end{array}$ & $\begin{array}{c}1 \\
(0.04)\end{array}$ & $\begin{array}{c}59 \\
(0.09)\end{array}$ & 0.13 \\
\hline ¿Trisopterus & $\begin{array}{c}238 \\
(5.06)\end{array}$ & $\begin{array}{c}109 \\
(12.1)\end{array}$ & $\begin{array}{c}247 \\
(3.86)\end{array}$ & $\begin{array}{c}54 \\
(3.18)\end{array}$ & $\begin{array}{c}7 \\
(0.25)\end{array}$ & $\begin{array}{c}75 \\
(1.53)\end{array}$ & $\begin{array}{c}90 \\
(2.05)\end{array}$ & $\begin{array}{c}1204 \\
(6.40)\end{array}$ & $\begin{array}{c}127 \\
(1.14)\end{array}$ & $\begin{array}{c}242 \\
(8.07)\end{array}$ & $\begin{array}{c}22 \\
(1.29)\end{array}$ & $\begin{array}{c}378 \\
(15.8)\end{array}$ & $\begin{array}{c}2793 \\
(4.45)\end{array}$ & 6.30 \\
\hline ¿All Gadidae & $\begin{array}{c}442 \\
(9.40)\end{array}$ & $\begin{array}{c}121 \\
(13.4)\end{array}$ & $\begin{array}{c}361 \\
(5.64)\end{array}$ & $\begin{array}{c}70 \\
(4.12)\end{array}$ & $\begin{array}{c}19 \\
(0.68)\end{array}$ & $\begin{array}{c}105 \\
(2.14)\end{array}$ & $\begin{array}{c}261 \\
(5.93)\end{array}$ & $\begin{array}{c}1703 \\
(9.06)\end{array}$ & $\begin{array}{c}347 \\
(3.13)\end{array}$ & $\begin{array}{c}650 \\
(5.85)\end{array}$ & $\begin{array}{c}69 \\
(4.06)\end{array}$ & $\begin{array}{l}540 \\
(22.5)\end{array}$ & $\begin{array}{l}4707 \\
(7.46)\end{array}$ & 10.6 \\
\hline Herring & $\begin{array}{c}2 \\
(0.04)\end{array}$ & $\begin{array}{c}0 \\
(0)\end{array}$ & $\begin{array}{c}3 \\
(0.05)\end{array}$ & $\begin{array}{c}7 \\
(0.41)\end{array}$ & $\begin{array}{c}1 \\
(0.04)\end{array}$ & $\begin{array}{c}116 \\
(2.37)\end{array}$ & $\begin{array}{c}58 \\
(1.32)\end{array}$ & $\begin{array}{c}382 \\
(2.03)\end{array}$ & $\begin{array}{c}51 \\
(0.46)\end{array}$ & $\begin{array}{c}4 \\
(0.13)\end{array}$ & $\begin{array}{c}2 \\
(0.12)\end{array}$ & $\begin{array}{c}0 \\
(0)\end{array}$ & $\begin{array}{c}626 \\
(1.00)\end{array}$ & 1.41 \\
\hline Garfish & $\begin{array}{c}0 \\
(0)\end{array}$ & $\begin{array}{c}0 \\
(0)\end{array}$ & $\begin{array}{c}0 \\
(0)\end{array}$ & $\begin{array}{c}0 \\
(0)\end{array}$ & $\begin{array}{c}0 \\
(0)\end{array}$ & $\begin{array}{c}1 \\
(0.02)\end{array}$ & $\begin{array}{c}0 \\
(0)\end{array}$ & $\begin{array}{c}27 \\
(0.14)\end{array}$ & $\begin{array}{c}118 \\
(1.06)\end{array}$ & $\begin{array}{c}9 \\
(0.30)\end{array}$ & $\begin{array}{c}7 \\
(0.41)\end{array}$ & $\begin{array}{c}4 \\
(0.17)\end{array}$ & $\begin{array}{c}166 \\
(0.26)\end{array}$ & 0.37 \\
\hline$\sum$ All pelagic fish & $(0.11)$ & $\begin{array}{c}2 \\
(0.22)\end{array}$ & $\begin{array}{c}10 \\
(0.16)\end{array}$ & $\begin{array}{c}8 \\
(0.47)\end{array}$ & $\begin{array}{c}1 \\
(0.04)\end{array}$ & $\begin{array}{c}117 \\
(2.39)\end{array}$ & $\begin{array}{c}58 \\
(1.32)\end{array}$ & $\begin{array}{c}426 \\
(2.27)\end{array}$ & $\begin{array}{c}179 \\
(1.61)\end{array}$ & $\begin{array}{c}14 \\
(0.47)\end{array}$ & $\begin{array}{c}12 \\
(0.71)\end{array}$ & $\begin{array}{c}4 \\
(0.17)\end{array}$ & $\begin{array}{c}792 \\
(1.26)\end{array}$ & 1.79 \\
\hline ¿Sandeels & $\begin{array}{l}1484 \\
(31.6)\end{array}$ & $\begin{array}{c}19 \\
(2.11)\end{array}$ & $\begin{array}{l}8108 \\
(127)\end{array}$ & $\begin{array}{l}2328 \\
(137)\end{array}$ & $\begin{array}{l}2608 \\
(93.1)\end{array}$ & $\begin{array}{c}3691 \\
(75.3)\end{array}$ & $\begin{array}{c}1794 \\
(40.8)\end{array}$ & $\begin{array}{l}10985 \\
(58.4)\end{array}$ & $\begin{array}{c}4576 \\
(41.2)\end{array}$ & $\begin{array}{c}1411 \\
(47.0)\end{array}$ & $\begin{array}{c}184 \\
(10.8)\end{array}$ & $\begin{array}{c}1516 \\
(63.2)\end{array}$ & $\begin{array}{l}38704 \\
(61.6)\end{array}$ & 87.3 \\
\hline$\sum$ All species & $\begin{array}{c}1953 \\
(41.6)\end{array}$ & $\begin{array}{c}142 \\
(15.8)\end{array}$ & $\begin{array}{l}8483 \\
(133)\end{array}$ & $\begin{array}{l}2413 \\
(142)\end{array}$ & $\begin{array}{c}2644 \\
(94.4)\end{array}$ & $\begin{array}{l}3914 \\
(79.9)\end{array}$ & $\begin{array}{c}2116 \\
(48.1)\end{array}$ & $\begin{array}{l}13137 \\
(69.9)\end{array}$ & $\begin{array}{l}5120 \\
(46.1)\end{array}$ & $\begin{array}{c}2076 \\
(69.2)\end{array}$ & $\begin{array}{c}265 \\
(15.6)\end{array}$ & $\begin{array}{c}2062 \\
(85.9)\end{array}$ & $\begin{array}{l}44325 \\
(70.6)\end{array}$ & 100 \\
\hline
\end{tabular}


son was significant $(H=81.85, \mathrm{p}<$ $0.0005)$. Herring were more numerous in quarter 3 than in quarters 1,2 and $4(p<$ $0.00005, p=0.0001$ and $p<0.00005$ respectively), and more numerous in quarter 2 than in quarter 1 ( $p=0.0036)$. Garfish was most common during September and November (1.06 and 0.41 respectively). Overall variation in the number of garfish otoliths per faex in relation to season was significant $(H=$ 35.04, $p<0.0005)$. Garfish were more numerous in quarter 3 than in quarter 2 $(p=0.002)$. Numbers of sandeel otoliths were highest during March and April (127 and 137), after which they declined towards the end of the year and the lowest values were generally observed during winter (Table 2). Overall variation in the number of sandeel otoliths per faex in relation to season was significant $(H=33.77, p<$ 0.0005 ). Sandeel were more numerous in quarter 2 than in quarters 1 ( $p=0.0003), 3$ and 4 ( $p<0.00005$ in both cases). Sandeels were also more numerous in quarter 1 than in quarter $3(p<0.0001)$.

\section{Diet composition by weight}

Gadid fish contributed between 20.6 and $87.4 \%$ to the diet by month throughout the year, and accounted for $53.4 \%$ of the annual diet (Table 3 ). A clear temporal trend was evident: after February, gadids declined markedly in importance to reach their lowest value during the spring/early summer. Between July and December, gadids generally increased in importance
(Fig. 2, Table 3). Whiting and saithe were the most important gadid species, contributing an estimated $36.4 \%$ of the annual diet. Haddock was the least important, contributing only $0.9 \%$ of the annual diet.

Pelagic fishes began to increase in importance after May to reach a peak during July to September and then sharply decreased towards the end of the year (Fig. 2). Herring was the most important pelagic species in the diet; during June and July, herring accounted for 32.3 and $16.1 \%$ of the diet respectively. Garfish replaced herring as the main pelagic species after August, peaking during September when it formed $34.1 \%$ of the diet, making it the top single species during September (Table 3). Overall, pelagic fish accounted for $13.8 \%$ of the annual diet of harbour seals.

Table 3. Monthly variation in the diet, by percentage weight, of harbour seals Phoca vitulina along the southeast Shetland coast, as derived from the measurement of otoliths and cephalopod beaks found in faeces

\begin{tabular}{|c|c|c|c|c|c|c|c|c|c|c|c|c|c|}
\hline Species & Jan & Feb & Mar & Apr & May & Jun & Jul & Aug & Sep & Oct & Nov & Dec & $\begin{array}{l}\text { Annual } \\
\text { average }\end{array}$ \\
\hline Cod & 0.3 & 0.0 & 1.6 & 0.7 & 0.0 & 0.7 & 0.0 & 2.8 & 0.9 & 0.5 & 3.9 & 0.2 & 1.0 \\
\hline Haddock & 0.2 & 4.3 & 0.7 & 1.7 & 0.2 & 0.0 & 0.8 & 1.1 & 0.3 & 0.0 & 0.0 & 1.8 & 0.9 \\
\hline Saithe & 26.4 & 0.0 & 3.4 & 0.0 & 3.2 & 1.8 & 8.8 & 5.1 & 6.2 & 4.5 & 29.5 & 44.5 & 11.1 \\
\hline Whiting & 17.3 & 35.3 & 23.4 & 189 & 5.0 & 7.2 & 49.6 & 27.9 & 21.9 & 48.9 & 17.2 & 31.2 & 25.3 \\
\hline Ling & 10.5 & 18.0 & 4.1 & 1.8 & 11.6 & 10.4 & 0.4 & 3.0 & 7.7 & 10.1 & 1.0 & 0.7 & 6.6 \\
\hline ¿Trisopterus & 14.5 & 29.6 & 8.9 & 6.3 & 0.5 & 1.8 & 3.5 & 9.3 & 2.5 & 6.1 & 4.0 & 8.2 & 7.9 \\
\hline ¿All Gadidae & 71.9 & 87.4 & 43.3 & 29.3 & 20.6 & 21.9 & 63.9 & 49.7 & 40.0 & 70.6 & 55.9 & 86.6 & 53.4 \\
\hline Herring & 0.4 & 0.0 & 0.3 & 2.6 & 0.9 & 32.3 & 16.1 & 23.9 & 5.9 & 1.8 & 3.3 & 0.0 & 7.3 \\
\hline Garfish & 0.0 & 0.0 & 0.0 & 0.0 & 0.0 & 0.4 & 0.0 & 5.2 & 34.1 & 8.3 & 9.3 & 1.2 & 4.9 \\
\hline ¿All pelagic fish & 1.0 & 3.7 & 0.4 & 5.2 & 0.9 & 32.7 & 16.1 & 31.4 & 42.5 & 12.4 & 17.6 & 1.2 & 13.8 \\
\hline ¿Sandeels & 21.1 & 2.5 & 55.5 & 64.0 & 67.0 & 43.9 & 18.8 & 15.8 & 15.3 & 16.8 & 11.6 & 10.0 & 28.5 \\
\hline EOther fish & 1.2 & 6.4 & 0.0 & 6.6 & 2.9 & 0.1 & 0.0 & 2.1 & 1.3 & 0.2 & 0.0 & 0.0 & 1.7 \\
\hline ¿Cephalopods & 4.3 & 0.0 & 0.6 & 0.0 & 1.5 & 1.3 & 1.2 & 0.7 & 0.3 & 0.6 & 15.0 & 2.9 & 2.4 \\
\hline
\end{tabular}


The importance of sandeels also showed clear evidence of seasonal trends, increasing after February and dominating the diet from March to June (Fig. 2). Sandeels contributed between 2.5 and $67.0 \%$ of the diet by month throughout the year and accounted for $28.5 \%$ of the annual harbour seal diet (Table 3). Generally, when sandeels were dominant in the diet (February to June), gadid fishes were least important and vice versa (Fig. 2).

Cephalopods were generally of highest importance during November to January; during November they accounted for $15 \%$ of the diet by weight (Table 3). However, overall they were of minor importance, accounting for $2.4 \%$ of the diet by weight.

\section{Sizes of fish consumed}

Length frequency distributions were constructed to allow examination of the estimated lengths of fish consumed. For sandeels (Fig. 3), distributions are on a monthly basis (except February) and for the other main species in the diet cod, haddock, ling, whiting, Norway pout, poor cod, herring and garfish), data were pooled over the study period (Fig. 4). For the 4 species with largest sample sizes (whiting, ling, sandeel and Trisopterus), monthly trends in mean size eaten are also shown (Fig. 5).

The size distribution for sandeels eaten by seals was unimodal in every month except November (Fig. 3). Overall variation in sandeel size in relation to season was significant (Kruskal-Wallis; $H=548.75, p<0.0005$ ). Sandeels eaten in quarters 1 and 2 were larger than those eaten in quarters 3 and 4 ( $p<$ 0.0005 ) and those eaten in quarter 3 were larger than those eaten in quarter $4(\mathrm{p}<0.00005)$. Overall variation in relation to month was also significant $(H=1091.91, \mathrm{p}<0.0005)$. Generally the size of sandeels declined with month (Fig. 5c) (Spearman's rank correlation $r=-0.435$ ) with the largest sandeels eaten in January to March and the smallest in August, September and December (see Table 4a).

All cod eaten (Fig. 4) were less than $50 \mathrm{~cm}$ in estimated length; the modal size was around 20 to $30 \mathrm{~cm}$
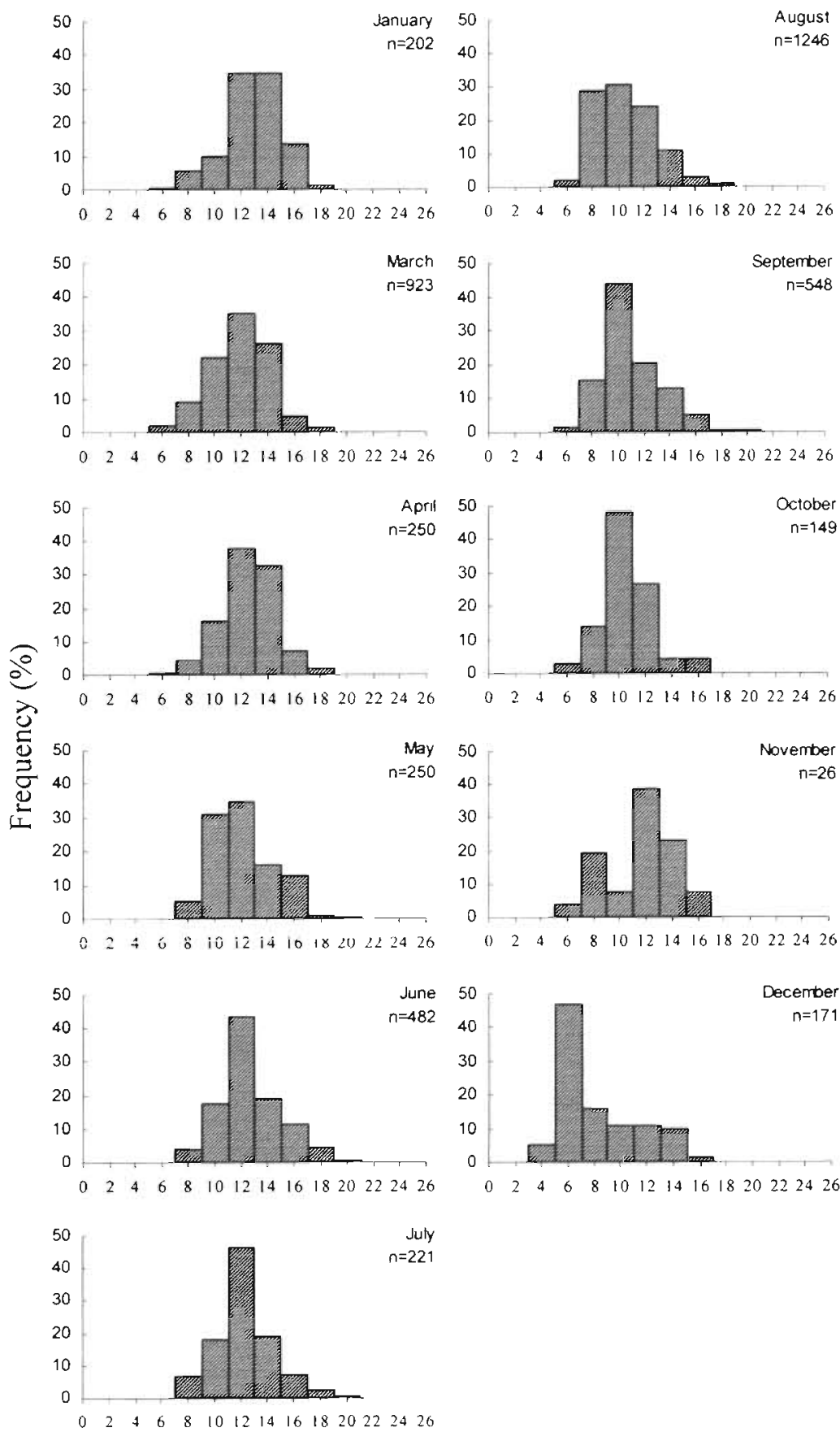

Length Class $(\mathrm{cm})$

Fig. 3. Length-frequencies of sandeels consumed by Phoca vitulina as a percentage of the monthly total

with the distribution being slightly skewed towards larger fish. Slightly more than $20 \%$ of the cod eaten were in excess of the minimum legal landing size (MLS) of $35 \mathrm{~cm}$.

Haddock (Fig. 4) had a modal size of 30 to $35 \mathrm{~cm}$ with the distribution being skewed towards smaller fish. 
Approximately $40 \%$ of the haddock eaten were in excess of the MLS of $30 \mathrm{~cm}$.

Whiting (Fig. 4) had 2 modes in the distribution, the first at 16 to $20 \mathrm{~cm}$ and a second, larger, mode at 32 to $36 \mathrm{~cm}$. Approximately $60 \%$ of the whiting eaten were in excess of the MLS of $27 \mathrm{~cm}$. Overall variation in whiting size in relation to season was significant ( $\mathrm{H}=$ 427.6, $p<0.0005$ ). Whiting eaten in quarters 2 and 3 were larger than those eaten in quarter $1(p=0.0001$ and $p=0.0005$ respectively), and whiting eaten in quarters 1,2 and 3 were larger than those taken in quarter 4 ( $p<0.00005$ in all cases). When the data were analysed on a month to month basis, whiting eaten in January, March and April were found to be generally larger than those eaten in other months (Table $4 \mathrm{~b}$, Fig 5a).

The modal size of ling was 30 to $40 \mathrm{~cm}$ (Fig. 4) but the distribution was skewed towards larger fish, with approximately $50 \%$ of the ling eaten being in excess of the MLS of $46 \mathrm{~cm}$. There was no clear seasonal pattern in size (Fig. 5b).

Saithe (Fig. 4) had a clumped distribution around 20 to $35 \mathrm{~cm}$, which accounts for more than $70 \%$ of all the saithe eaten. Less than $20 \%$ of all the saithe eaten had lengths in excess of the MLS of $35 \mathrm{~cm}$. Overall variation in saithe size in rela-
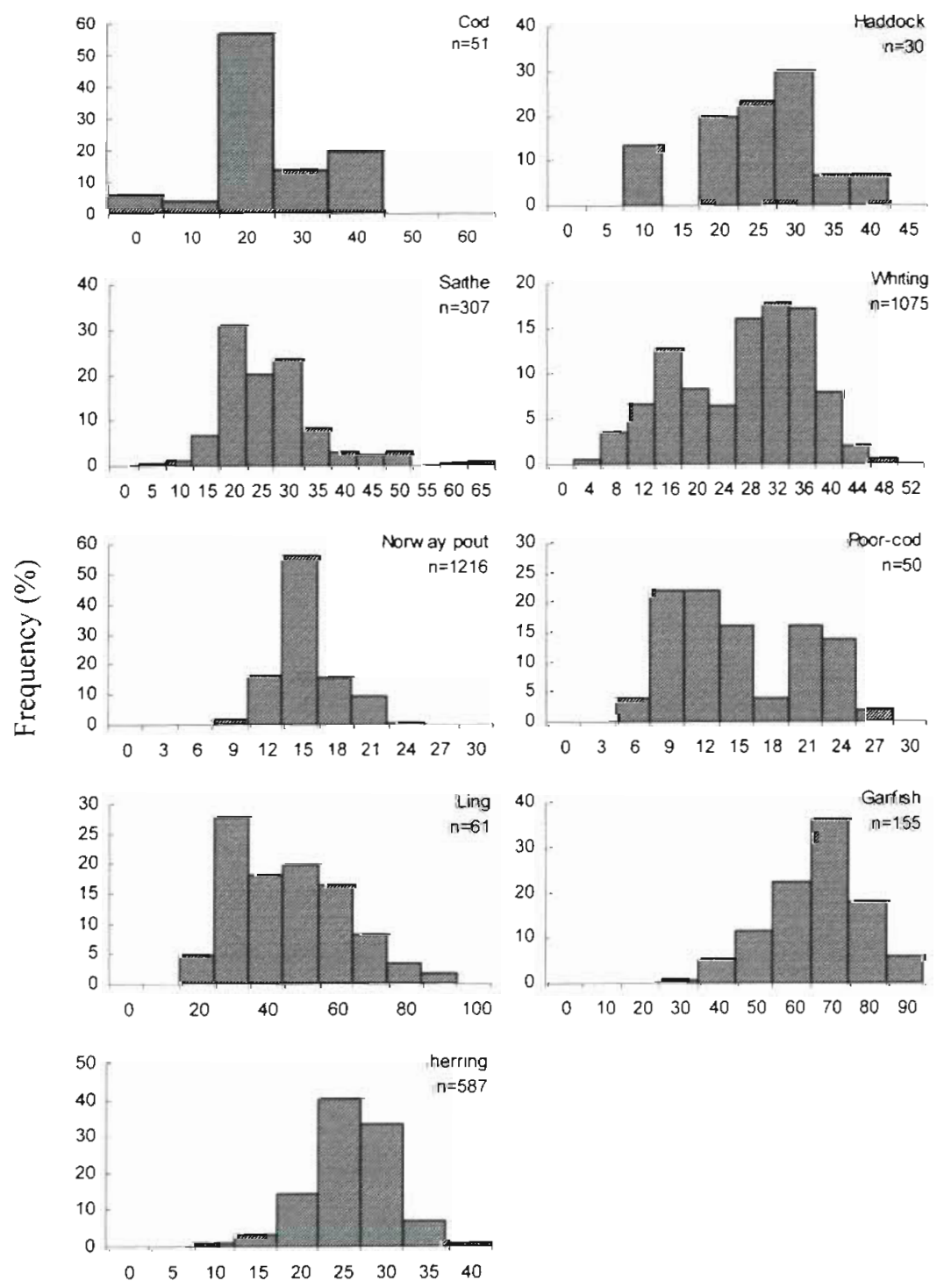

Length Class (cm)

Fig. 4. Length-trequencies of fish consumed by Phoca vitulina as a percentage of the total, for cod, haddock, saithe, whiting, Norway pout, poor cod, ling, garfish and herring in spring and summer tion to season was significant $(H=$ 58.53, $p<0.0005)$. Saithe eaten in quarters 3 and 4 were larger than those taken in quarter $1(p<0.00005$ in both cases\}.

Poor cod (Fig. 4) had 2 modes in the distribution, the first around 9 to $15 \mathrm{~cm}$ (40\% of all fish) and a second larger mode at 21 to $27 \mathrm{~cm}$ ( $30 \%$ of all fish). Overall variation in poor cod size in relation to season was significant ( $H=$ 13.36, $p=0.004$ ). Poor cod eaten in quarters 1 and 3 were larger than those taken in quarter 4 ( $p<0.0007$ and $p<0.002$ respectively). Norway pout (Fig. 4) had a mode around 15 to $18 \mathrm{~cm}$. Overall variation in pout size in relation to season was significant ( $H=$ $194.9, p<0.0005$ ). Pout eaten in quarters 1, 2 and 3 were larger than those eaten in quarter 4 ( $p<0.00005$ in all cases). Taking the 2 Trisopterus species together, there was significant monthly variation in size $(H=650.41$, $p<0.0005)$. Generally, fish taken in January, March and April were larger than those taken in the rest of the year (Table 4c, Fig. 5d).

Herring (Fig. 4) had a mode at 25 to $30 \mathrm{~cm}$. Less than $5 \%$ of the herring eaten were smaller than the MLS of 20 cm for North Sea herring. Overall variation in herring size in relation to season was significant $(H=13.36, \mathrm{p}=$ 0.004). Herring eaten in quarter 3 were larger than those taken in quarter $2(p=0.001)$. Very few herring were taken in quarters 1 or 4 . Garfish (Fig. 4) had a clear mode at 70 to $80 \mathrm{~cm}$ and the distribution was skewed towards smaller fish. 

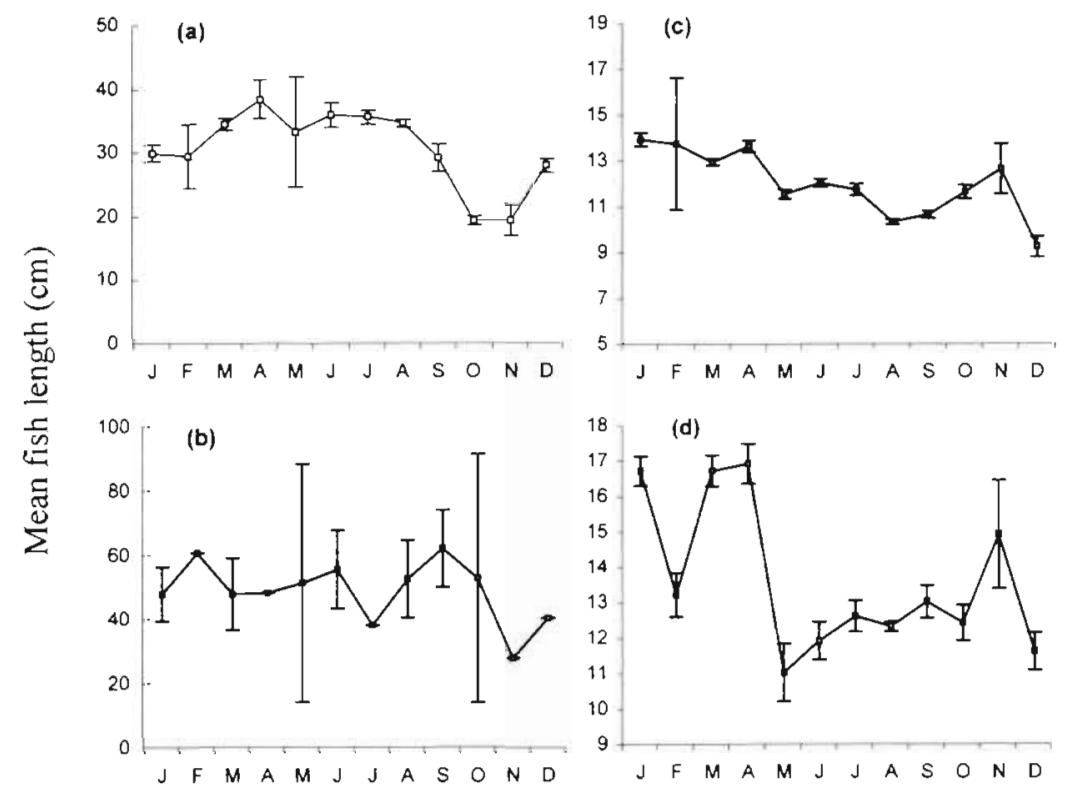

Month

Fig. 5. Monthly variation in the mean length of fish consumed by Phoca vitulina, for species where sufficient data were available for all months (error bars show 95\% CL): (a) whiting, $\mathrm{n}=1075$; (b) ling, $\mathrm{n}=58$; (c) sandeels, $\mathrm{n}=4326$; (d) Trisopterus spp., $\mathrm{n}=1616$

A modified estimate of diet composition was derived summing total prey weights for the main species or groups and applying the correction factors from Table 5. The contribution to the diet by weight was then re-scaled to sum to $100 \%$ (Table 6 ).

The apparent importance of gadids and sandeels is seen to decline slightly, whereas the importance of pelagic species increases, particularly for garfish (Table 6).

\section{DISCUSSION}

\section{Seasonal variation in diet}

Our results show strong seasonal trends in diet, with sandeels being the most important prey in March to June and gadids dominating the diet in much of the rest of the year. The importance of the third major category of prey, pelagic fish species, is probably significantly underestimated by basing conclusions on use of otoliths alone. Pelagic fish species were important in the diet during the summer

\section{Assessment of error associated with using otoliths to determine seal diet}

The frequencies with which different categories of prey were identified based on (1) otoliths alone and (2) all identifiable structures appear in Table 5. Comparisons using $\chi^{2}$ tests indicate a significant increase in frequency of identification, when all hard structures were used, for gadids ( $p<0.02 ; 15 \%$ increase), herring $(p<0.01 ; 41 \%)$, mackerel $(p<0.01 ; 323 \%)$ and garfish $(\mathrm{p}<0.01 ; 102 \%)$. Although the detection of flatfish increased by $47 \%$ using all hard parts, this increase was not significant $(p>0.10)$, reflecting the low incidence of this group in the diet.

\section{Correcting for samples containing no otoliths}

We calculated a series of correction factors, to account for samples that contain bones of a fish species but not otoliths, based on the percentage increase in frequency of detection (as shown in the last column of Table 5). We assume that the number and size of fish (of a particular category) in samples containing only the bones was the same as for an average sample in which otoliths were present. months. Garfish in particular appear to be seasonally important, especially in September.

The inshore commercial sandeel fishery takes place around Shetland during spring and early summer and it may therefore be assumed that their availability to seals in inshore waters is highest at this time. It is also generally assumed that sandeels overwinter buried in the substrate, although Tollit \& Thompson (1996) showed that sandeels may be available to seals in winter (see below).

Seasonal variation in the contribution of herring to the diet appears to broadly follow known migratory patterns. Herring migrate southwards past Shetland during late summer (J. Morrison, SOAEFD, Marine Lab., pers. comm.) and are likely to be at peak availability at some time during July to September, after which their continued migration would take them out of the range of the Shetland population of harbour seals.

The importance of garfish in the diet is worthy of comment, since this species has not been reported in seal diets in other areas of the North Sea. Garfish are occasionally by-caught with herring and mackerel by pelagic fishing vessels and have been observed inshore around Shetland in recent years (Brown pers. obs.). 
Since it is not commercially exploited in northern European waters, little is known about the biology of garfish. Garfish are surface living, being found in the shallow waters of northern Europe, and can often be found close inshore during summer and autumn (Wheeler 1978). Recent studies (Dorman 1989, 1991) have shown that the species is caught regularly in the waters around southern Britain and Ireland and appears to come inshore around June to spawn. According to Muus \& Dahlstrom (1977) it follows a migratory pattern similar to that observed in Atlantic mackerel, entering the North Sea in March-April and towards the end of the year migrating to waters to the west and south of the British Isles.

In the present study, predation by seals on garfish peaked in the autumn, when the species is expected to be found inshore. Presumably this corresponds with peak abundance of garfish along the southeast Shetland coast.

Gadid fishes were most important in the diet over the winter months. However, there are no data available on the seasonal movements of species such as saithe or whiting inshore around Shetland to make an assessment of their availability. Neither sandeels nor herring

Table 4. Monthly comparisons of otolith sizes for sandeels, whiting and Trisopterus spp., as derived from the measurement of otoliths found in harbour seal Phoca vitulina faeces. The table indicates the significance of differences in median otolith size. Probabilities accepted as indicating significance are based on the use of a Bonferroni correction: ${ }^{\circ} p<0.00076 ;{ }^{\cdot 0.00076} \leq p<0.05$; NS: $p \geq 0.05$

\begin{tabular}{|c|c|c|c|c|c|c|c|c|c|c|c|}
\hline & Jan & Feb & Mar & Apr & May & Jun & Jul & Aug & Sep & $O c t$ & Nov \\
\hline \multicolumn{12}{|c|}{ (a) Sandeel } \\
\hline Feb & NS & & & & & & & & & & \\
\hline Mar & $\cdots$ & NS & & & & & & & & & \\
\hline Apr & $\because$ & $\cdot$ & $\cdots$ & & & & & & & & \\
\hline May & $\cdots$ & $\cdot$ & $\cdots$ & NS & & & & & & & \\
\hline Jun & $\cdots$ & NS & $\cdots$ & $\cdot$ & $\cdots$ & & & & & & \\
\hline Jul & $\because$ & $\cdot$ & $\cdots$ & •" & $\cdot$ & NS & & & & & \\
\hline Aug & $\cdots$ & $\cdot$ & $\cdots$ & $\cdot$ & $\cdots$ & $\cdots$ & $\cdots$ & & & & \\
\hline Sep & $\cdots$ & $\cdot$ & $\cdots$ & NS & $\cdots$ & $\cdots$ & $\cdots$ & $\cdots$ & & & \\
\hline Oct & $\cdots$ & $\cdot$ & $\cdots$ & NS & NS & $\cdot$ & NS & $\because$ & $\cdot$ & & \\
\hline Nov & $\cdot$ & NS & NS & $\cdot$ & $\cdot$ & NS & $\cdot$ & $\cdots$ & $\cdots$ & $\cdot$ & \\
\hline Dec & $\cdots$ & $\cdot$ & $\cdot$ & $\cdots$ & $\because$ & $\cdots$ & $\because$ & $\because$ & $\cdots$ & 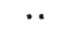 & $\because$ \\
\hline \multicolumn{12}{|c|}{ Rank order of months: Jan $>$ Feb $>$ Mar $>$ Nov $>$ Jun $>$ Jul $>$ Oct $>$ May $>$ Apr $>$ Sep $>$ Aug $>$ Dec } \\
\hline \multicolumn{12}{|c|}{ (b) Whiting } \\
\hline Feb & NS & & & & & & & & & & \\
\hline Mar & $\cdot \cdot$ & NS & & & & & & & & & \\
\hline Apr & $\cdots$ & $\cdot$ & $\cdot$ & & & & & & & & \\
\hline May & $\cdot$ & NS & $\cdots$ & $\cdot$ & & & & & & & \\
\hline Jun & $\cdots$ & $\cdot$ & $\cdots$ & $\because$ & NS & & & & & & \\
\hline Jul & $\cdots$ & $\cdot$ & $\cdots$ & $\cdot \cdot$ & NS & NS & & & & & \\
\hline Aug & $\cdots$ & $\cdot$ & $\cdots$ & $\cdots$ & NS & NS & NS & & & & \\
\hline Sep & $\cdots$ & $\cdot$ & $\cdots$ & $\cdot \cdot$ & NS & NS & $\cdot$ & . & & & \\
\hline Oct & $\cdots$ & $\because$ & 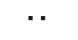 & $\cdot \cdot$ & NS & $\cdots$ & $\cdots$ & .. & $\cdot$ & & \\
\hline Nov & . & $\cdot$ & $\cdots$ & . & NS & $\cdots$ & $\cdots$ & $\cdots$ & NS & NS & \\
\hline Dec & $\cdot$ & NS & $\cdots$ & $\cdots$ & $\cdot$ & $\cdot$ & $\cdots$ & $\cdots$ & $\cdot \cdot$ & $\cdot \cdot$ & $\cdots$ \\
\hline \multicolumn{12}{|c|}{ Rank order of months: Apr $>$ Mar $>$ Jan $>$ Feb $>$ Dec $>$ Jun $>$ Jul $>$ Aug $>$ May $>$ Sep $>$ Nov $>$ Oct } \\
\hline \multicolumn{12}{|c|}{ (c) Trisopterus } \\
\hline Feb & ". & & & & & & & & & & \\
\hline Mar & NS & $\cdots$ & & & & & & & & & \\
\hline Apr & NS & $\because$ & NS & & & & & & & & \\
\hline May & $\cdot$ & $\cdot$ & $\cdots$ & $\cdots$ & & & & & & & \\
\hline Jun & $\because$ & $\cdot$ & $\because$ & $\cdots$ & NS & & & & & & \\
\hline Jul & $\because$ & NS & $\cdots$ & 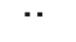 & $\cdot$ & ' & & & & & \\
\hline Aug & $\cdot \cdot$ & • & $\cdots$ & $\cdots$ & $\cdot$ & • & NS & & & & \\
\hline Sep & $\cdots$ & NS & $\cdots$ & $\cdot \cdot$ & $\cdot$ & $\cdots$ & $\cdot$ & 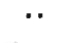 & & & \\
\hline Oct & $\cdots$ & $\cdot$ & $\because$ & $\cdots$ & NS & NS & NS & NS & $\cdot$ & & \\
\hline Nov & $\cdot$ & $\cdot$ & NS & NS & " & $\cdots$ & $\cdot$ & $\cdots$ & " & $\cdot$ & \\
\hline Dec & $\cdots$ & $\cdots$ & $\cdots$ & $\cdots$ & NS & NS & $\cdots$ & $\because$ & $\cdots$ & NS & $\because$ \\
\hline
\end{tabular}


Table 5. Number of Phoca vitulina faecal samples containing prey belonging to that group or species, for (A) using only otoliths to identify prey and (B) using all diagnostic bone structures (including otoliths) to identify prey. Difference between the identifications is expressed as a percentage change

\begin{tabular}{|lrrc|}
\hline Species/group & \multicolumn{2}{c}{$\begin{array}{c}\text { No. of identifications } \\
\text { based on }\end{array}$} & $\begin{array}{c}\text { Increase } \\
100 \times(\mathrm{B} / \mathrm{A})-100 \\
(\mathrm{\omega} / \%)\end{array}$ \\
\hline Gadidae & $\mathrm{A}$ & $\mathrm{B}$ & +15 \\
Sandeels & 329 & 377 & +1 \\
Flatfish & 316 & 318 & +47 \\
Herring & 19 & 28 & +41 \\
Mackerel & 153 & 215 & +323 \\
Garfish & 13 & 55 & +102 \\
\hline
\end{tabular}

are likely to be available in high densities in winter and this may be a feasible explanation for the observed increase in consumption of gadids.

\section{Comparisons with other studies}

The range of prey species seen in the present study was broadly similar to that reported for other studies of harbour seal feeding in Scottish waters, with sandeels and Gadidae figuring prominently in the diet. However, fceding oni gâuffish has nui been reported in other studies.

In the Moray Firth area of Scotland, Pierce et al. (1991b) reported that clupeids predominated in winter diets and sandeels in summer diets during 1988. The decline in importance of sandeels in the diet towards the end of the year is also recorded for grey seals (Prime \& Hammond 1990). In the Kattegat and Skagerrak, sandeels reached their highest contribution to the diet of harbour seals during April to June (18\%; Härkönen 1987). These observations are consistent with the temporal pattern observed in the contribution of sandeels to the diet of harbour seals in the present study. The decline in importance of sandeels in winter is not always observed, however, Tollit \& Thompson (1996) found that consumption of sandeels by harbour seals in the Moray Firth remained high in the winters of 1989-90,1990-91 and 1991-92, years in which clupeid abundance in the Firth was low.

Härkönen (1987) reported cod to contribute 12 to $22 \%$ to the diet by weight, depending on the season. Our results show that cod only con- tributes $1 \%$ to the annual diet of harbour seals inshore along the southeast Shetland coast, and cod was generally unimportant in the Moray Firth diet (1988 to 1992), except in the winter of 1991-92 (Pierce et al. 1991b, Tollit \& Thompson 1996).

The most evident difference between the diets of harbour seals in Danish and Shetland waters is the contribution of flatfishes to the diet. Härkönen (1987) reported the maximum contribution to be $34 \%$ for any one season. Along the southeast Shetland coastline, flatfishes contributed less than $1 \%$ of the annual diet. In the Moray Firth, flatfish contributed less than $20 \%$ to summer diets in 1988 and 1990-1992, being absent altogether in the 1989 diet (Pierce et al. 1991b, Tollit \& Thompson 1996).

There is little quantitative information available from other studies on the diet of harbour seals to allow comparison of the sizes of fish consumed. Olsen \& Bjorge (1995) reported that the size of fish consumed by harbour seals in Norway ranged from 5 to $92 \mathrm{~cm}$. We found a similar range, 3 to $99 \mathrm{~cm}$. Tollit \& Thompson (1996) reported that the mean size of whiting eaten by harbour seals, in the Moray Firth, ranged from 8.7 to $11.9 \mathrm{~g}$. Our data showed that whiting eaten by harbour seals along the southeast Shetland coast had a mean weight of $245 \mathrm{~g}$, markedly larger that those in the Moray Firth. The Moray Firth is a nursery area for herring, sprat and small gadids (Hopkins, 1986) and it is, therefore, not surprising to find that harbour seals exploit this abundant small prey in areas such as the Moray Firth.

The question remains as to whether harbour seals around Shetland are deliberately selecting larger prey in Shetland waters or if the fish available are generally larger than elsewhere. It is possible that some of the fish eaten include discarded fish. Seals are sometimes by-caught by whitefish boats working inshore (Brown pers. obs.). Discards form an important part of the diet of some seabirds (Evans et al. 1994, Garthe \& Huppop

Table 6. Percentage diet by weight for the main Phoca vitulina prey species and groups, before and after correction factors to account for samples containing no otoliths were applied

\begin{tabular}{|lrrrrrr|}
\hline $\begin{array}{l}\text { Species } \\
\text { or group }\end{array}$ & $\begin{array}{c}\text { Initial } \\
\text { weight }(\mathrm{g})\end{array}$ & $\begin{array}{c}\text { \% weight } \\
\text { (A) }\end{array}$ & $\begin{array}{c}\text { Correction } \\
\text { factor }\end{array}$ & $\begin{array}{c}\text { Corrected } \\
\text { weight }(\mathrm{g})\end{array}$ & $\begin{array}{r}\text { \% weight } \\
(\mathrm{B})\end{array}$ & $\begin{array}{c}\text { Difference } \\
(\mathrm{B}-\mathrm{A})\end{array}$ \\
\hline Gadidae & 265860 & 49.2 & 1.15 & 305739 & 45.7 & -3.5 \\
Herring & 72068 & 13.3 & 1.41 & 101616 & 15.1 & +1.8 \\
Mackerel & 5208 & 1.0 & 3.23 & 16822 & 2.5 & +1.5 \\
Garfish & 44252 & 8.2 & 2.02 & 89389 & 13.3 & +5.1 \\
All pelagic & 124805 & 23.1 & 1.69 & 211104 & 31.4 & +8.3 \\
Flatfish & 2689 & 0.5 & 1.47 & 3953 & 0.6 & +0.1 \\
Sandeels & 134226 & 24.8 & 1.01 & 135568 & 20.2 & -4.6 \\
Others & 12720 & 2.4 & 1.00 & 12720 & 1.9 & -0.5 \\
\hline
\end{tabular}


1994, Garthe et al. 1996) but their importance for other piscivores is not well known. Herring, mackerel and garfish are all fast swimming species and their presence in discards might explain why seals were able to take them in relatively large numbers. However, this would not explain why harbour seals feed on these species when there is no pelagic fishing vessel activity in the area, e.g. peak predation on garfish occurs after the bulk of the herring would have migrated past Shetland, and fishing effort would have moved away to follow the herring shoals.

\section{Methodology; use of bones to identify fish prey and implications for diet estimates}

The methodology used in this study, based on faeces collected at haul-out sites, is expected to have provided representative information on the diet of seals feeding locally. Telemetry studies have shown that harbour seals are essentially inshore feeders (Thompson \& Miller 1990, Thompson 1993) and it can therefore be argued that most feeding will be represented in faeces found on the haul-out. The number of samples collected varied from month to month, reflecting changing availability, as also reported by Pierce et al. (1991b) and Hammond et al. (1994a, b). As is usual in such studies, the 'weighting' given to each faex was determined solely by the weight of prey represented by the hard remains contained therein. Alternative formulations (e.g. equal weighting for each faex, equal total weighting for faeces for each month) are possible but were not explored here.

Our results clearly show that some species or groups of fish are likely to be underestimated by using only the otoliths found in faecal samples, particularly those with small or fragile otoliths (e.g. herring, mackerel and salmon). There was a $323 \%$ increase in the apparent incidence of mackerel when all identifiable mackerel remains were used as opposed to only otoliths. Boyle et al. (1990) reported that during a captive feeding experiment they recovered only 1 salmon otolith out of a total of 38 ingested ( $2.6 \%$ recovery rate). Cottrell et al. (1996) reported an average recovery rate of $54 \%$ for otoliths of several species of fish fed to captive harbour seals. They also found that using bone structures other than otoliths significantly improved the detection of prey species and concluded, 'identifying several different prey structures increases the likelihood of identifying a prey type'.

Prime \& Hammond (1990) argued that traditional faecal analysis, based on identification and measurement of otoliths, does not miss any significant part of the diet. SMRU (1984) compared the energy content of several grey seal faeces from the southwestern North
Sea with the energy content of the fish represented by the otoliths in the faeces, and found that the ratio of the 2 values was consistent with reported values for assimilation efficiency. Thus no major component of the diet was missed. However, their samples were collected in an area of the North Sea where the seals were unlikely to encounter salmonid or pelagic fishes.

Recent work has been directed towards refining digestion coefficients to account for partial digestion of the otolith while in the seal's gut (e.g. Tollit et al. 1997), rather than dealing with loss or complete digestion of otoliths. Brown \& Pierce (1997) reported that the percentage composition of the diet by weight was relatively insensitive to the inclusion of experimentally derived correction factors. Our present work shows that the apparent diet composition is sensitive to the inclusion of fish represented by remains other than otoliths found in the faeces.

\section{Assessment of seal fisheries interactions}

The main species exploited by commercial fisheries around Shetland are haddock, whiting, ling, saithe and cod (Anon 1996b). One species that is important in local landings but was not detected in the harbour seal diet is the anglerfish Lophius piscatorius. This species has very small otoliths and a soft skeleton so it is possible that its remains would not be detected.

Our results show that the 5 main commercial species account for $45 \%$ of the annual diet of harbour seals in this area. However, many of the fish eaten were under the current legal minimum landing sizes. It remains difficult to quantify the degree of direct competition since:

(1) It is difficult to establish whether harbour seals are taking fish in the same area and at the same period of time as commercial fishing vessels because at present there are no data on where harbour seals are feeding in relation to the main centres of commercial fishing.

(2) The proportion of the small fish eaten which would have become available to fisheries in the future is unknown. Indeed, as discussed above, the seals could have been directly feeding on discarded fish.

Acknowledgements. This research was funded by the Shetland Wildlife Fund, Scottish Natural Heritage, The Hunter \& Morrison Trust and The Shetland Fishermen's Association. The authors wish to thank Martin Holmes at the North Atlantic Fisheries College for the use of laboratory facilities and equipment and Tom Jamieson for the boat trips to the Island of Mousa during the summer. John Hislop and 3 referees provided useful comments on an earlier draft of the paper 
Appendix 1. Regression equations used to predict fish lengths and weights from otolith measurements; sources (S) and digestion coefficients (DC) are also given. $\mathrm{B}=$ Bedford et al. (1986); $\mathrm{C}=$ Coull et al. (1989); $\mathrm{Cl}=$ Clarke (1986); $\mathrm{E}=\mathrm{E}$. $\mathrm{G}$. Brown (unpubl. data); H = Härkönen (1986); J = J. R. G. Hislop (unpubl. data); P = G. J. Pierce (unpubl. data) ${ }^{\circ}$ combined data. OL: otolith length; OW: otolith width; LHL: lower hood length; UHL: upper hood length; URL: upper rostral length; LRL: lower rostral length

\begin{tabular}{|c|c|c|c|c|c|}
\hline Species of fish with scientific name & Estimated fish length (mm) & $S$ & Estimated fish weight (g) & S & DC \\
\hline Cod Gadus morhua & $\begin{array}{l}F L=9.535\left(\mathrm{OL}^{1.475}\right) \\
F L=42.683\left(\mathrm{OW}^{1.300}\right)\end{array}$ & $\begin{array}{l}E \\
E\end{array}$ & $\begin{array}{l}F W=0.007823\left(\mathrm{OL}^{4.452569}\right) \\
F W=0.651869\left(\mathrm{OW}^{398696 .}\right)\end{array}$ & $\begin{array}{l}E \\
E\end{array}$ & $\begin{array}{l}1.070 \\
1.070\end{array}$ \\
\hline Haddock Melanogrammus aeglefinus & $\begin{array}{l}\mathrm{FL}=14.096\left(\mathrm{OL}^{1.193}\right) \\
\mathrm{FL}=45.897\left(\mathrm{OW}^{1215}\right)\end{array}$ & $\begin{array}{l}E \\
E\end{array}$ & $\begin{array}{l}F W=0.019742\left(\mathrm{OL}^{3.709555}\right) \\
F W=0.723869\left(\mathrm{OW}^{3793770}\right)\end{array}$ & $\begin{array}{l}E \\
E\end{array}$ & $\begin{array}{l}1.250 \\
1.240\end{array}$ \\
\hline Saithe Pollachius virens & $\begin{array}{l}\mathrm{FL}=13.829\left(\mathrm{OL}^{1.322}\right) \\
\mathrm{FL}=42.391\left(\mathrm{OW}^{1.525}\right)\end{array}$ & $\begin{array}{l}E \\
E\end{array}$ & $\begin{array}{l}F W=0.028654\left(\mathrm{OL}^{3.931842}\right) \\
F W=0.762794\left(\mathrm{OW}^{4.513928}\right)\end{array}$ & $\begin{array}{l}E \\
E\end{array}$ & $\begin{array}{l}1.250 \\
1.240\end{array}$ \\
\hline Haddock/saithe & $\begin{array}{l}\mathrm{FL}=16.274\left(\mathrm{OL} \mathrm{L}^{1.199}\right)^{\circ} \\
\mathrm{FL}=49.497(\mathrm{OW} / .269\end{array}$ & $\begin{array}{l}E \\
E\end{array}$ & $\begin{array}{l}F W=0.039122\left(\mathrm{OL}^{3.600289}\right)^{\circ} \\
F W=1.066829\left(\mathrm{OW}^{3.4485}\right)\end{array}$ & $\begin{array}{l}E \\
E\end{array}$ & $\begin{array}{l}1.250 \\
1.240\end{array}$ \\
\hline Ling Molva molva & $\begin{array}{l}F L=-128.038+(O L \times 67.634) \\
F L=-130.941+(O W \times 186.906)\end{array}$ & $\begin{array}{l}\mathrm{E} \\
\mathrm{E}\end{array}$ & $\begin{array}{l}F W=0.198199\left(\mathrm{OL}^{3.620808}\right) \\
F W=6.559731\left(\mathrm{OW}^{3.38733}\right)\end{array}$ & $\begin{array}{l}E \\
E\end{array}$ & $\begin{array}{l}1.250 \\
1.240\end{array}$ \\
\hline Whiting Merlangius merlangus & $\mathrm{FL}=-54.114+(\mathrm{O} W \times 79.671)$ & E & $F W=0.790806\left(O W^{3705954}\right)$ & E & 1.365 \\
\hline Norway pout Trisopterus esmarki & $\begin{array}{l}F L=-4.794+(\mathrm{OL} \times 23.624) \\
F L=-1.640+(\mathrm{O} W \times 55.204)\end{array}$ & $\begin{array}{l}E \\
E\end{array}$ & $\begin{array}{l}F W=0.046490\left(\mathrm{OL}^{3.324336}\right) \\
F W=0.886564\left(\mathrm{OW}^{3279030}\right)\end{array}$ & $\begin{array}{l}E \\
E\end{array}$ & $\begin{array}{l}1.250 \\
1.240\end{array}$ \\
\hline Poor cod Trisopterus minutus & $\begin{array}{l}F L=-66.617+(\mathrm{OL} \times 30.734) \\
F L=-34.836+(\mathrm{O} \times 56.691)\end{array}$ & $\begin{array}{l}\mathrm{E} \\
\mathrm{E}\end{array}$ & $\begin{array}{l}F W=0.002926\left(O L^{4.761464}\right) \\
F W=0.218384\left(O W^{421111}\right)\end{array}$ & $\begin{array}{l}E \\
E\end{array}$ & $\begin{array}{l}1.250 \\
1.240\end{array}$ \\
\hline Trisopterus spp. & 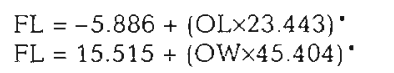 & $\begin{array}{l}E \\
E\end{array}$ & $\begin{array}{l}\mathrm{FW}=0.033918\left(\mathrm{OL}^{3.531259}\right)^{\circ} \\
\mathrm{FW}=0.916531\left(\mathrm{OW}^{3.157323}\right)^{\circ}\end{array}$ & $\begin{array}{l}E \\
E\end{array}$ & $\begin{array}{l}1.250 \\
1.240\end{array}$ \\
\hline Tusk/torsk Brosme brosme & $\mathrm{FL}=24.100+(\mathrm{OL} \times 44.424)$ & $\mathrm{E}$ & $\mathrm{FW}=0.005140\left(\mathrm{FLcm}^{3.189000}\right)$ & B & 1.250 \\
\hline Unidentified gadids & $\begin{array}{l}F L=-61.590+(O L \times 33.304)^{\circ} \\
F L=-54.350+(O W \times 76.582)^{\circ}\end{array}$ & $\begin{array}{l}\mathrm{H} \\
\mathrm{P}\end{array}$ & $\begin{array}{l}\left.F W=0.016042\left(\mathrm{FLcm}^{3035950}\right)^{303595}\right)^{\circ} \\
F W=0.016042\left(\mathrm{FLcmi}^{3}\right.\end{array}$ & $\begin{array}{c}\mathrm{B} / \mathrm{C} \\
\mathrm{P}\end{array}$ & $\begin{array}{l}1.250 \\
1.240\end{array}$ \\
\hline Ling/rockling & $\mathrm{FL}=36.900+(\mathrm{OL} \times 51.700)^{\circ}$ & $\mathrm{H} / \mathrm{P}$ & $F W=2.485710\left(\mathrm{OL}^{2.592760}\right)^{*}$ & $\mathrm{H} / \mathrm{P}$ & 1.250 \\
\hline Herring Clupea harengus & $F L=-87.490+(0 W \times 184.390)$ & $\mathrm{H}$ & $\mathrm{FW}=0.006030\left(\mathrm{FLcm}^{3.090400}\right)$ & $\mathrm{C}$ & 1.170 \\
\hline Mackerel Scomber scomberus & $\begin{array}{l}F L=41.363+(\mathrm{OL} \times 74.075) \\
F L=-33.539+(\mathrm{OW} \times 255.071)\end{array}$ & $\begin{array}{l}E \\
E\end{array}$ & $\begin{array}{l}F W=4.745687\left(\mathrm{OL}^{3129485}\right) \\
F W=78.642882\left(\mathrm{OW}^{4.046553}\right)\end{array}$ & $\begin{array}{l}E \\
E\end{array}$ & $\begin{array}{l}1.250 \\
1.240\end{array}$ \\
\hline Garfish Belone belone & $\mathrm{FL}=0.000+(\mathrm{OL} \times 140.000)$ & $\mathrm{H}$ & $\mathrm{FW}=0.000200\left(\mathrm{FLcm}^{3442000}\right)$ & $\mathrm{C}$ & 1.250 \\
\hline Scad Trachurus trachurus & $\begin{array}{l}F L=-27.020+(\mathrm{OL} \times 34.939) \\
\mathrm{FL}--20.110+(0 \mathrm{~W} \times 79.010)\end{array}$ & $\begin{array}{l}\mathrm{P} \\
\mathrm{P}\end{array}$ & $\begin{array}{l}\mathrm{FW}=0.003400\left(\mathrm{FLcm}^{3.294300}\right) \\
\mathrm{FW}=0.003400\left(\mathrm{FLcm}^{3} 294.300\right)\end{array}$ & $\hat{c}$ & $\begin{array}{l}1.250 \\
1.240\end{array}$ \\
\hline Sprat Sprattus sprattus & $\mathrm{FL}=-50.520+(\mathrm{OL} \times 151.950)$ & $\mathrm{J}$ & $\mathrm{FW}=0.002168\left(\mathrm{FLcm}^{3.474600}\right)$ & $\mathrm{C}$ & 1.090 \\
\hline Lemon sole Microstomus kitt & $\begin{array}{l}F L=10.930+(\mathrm{OL} \times 88.460) \\
F L=-71.440+(\mathrm{OW} \times 176.450)\end{array}$ & $\begin{array}{l}\mathrm{H} \\
\mathrm{P}\end{array}$ & $\begin{array}{l}\mathrm{FW}=0.026520\left(\mathrm{FLcm}^{2.764300}\right) \\
\mathrm{FW}=0.026520\left(\mathrm{FLcm}^{2.764300}\right)\end{array}$ & $\begin{array}{l}\mathrm{C} \\
\mathrm{C}\end{array}$ & $\begin{array}{l}1.230 \\
1.230\end{array}$ \\
\hline Dab Limanda limanda & $\begin{array}{l}F L=-50.960+(O L \times 58.470) \\
F L=-97.830+(O W \times 108.584)\end{array}$ & $\begin{array}{l}\mathrm{H} \\
\mathrm{P}\end{array}$ & $\begin{array}{l}F W=0.005450\left(\mathrm{FLcm}^{3.195000}\right) \\
F W=0.007400\left(\mathrm{FLcm}^{1.12800}\right)\end{array}$ & B & $\begin{array}{l}1.250 \\
1.240\end{array}$ \\
\hline Bothidae & $\mathrm{FL}=-11.420+(\mathrm{OL} \times 54.770)^{\circ}$ & $\mathrm{H}$ & $\mathrm{FW}=0.024920\left(\mathrm{FLcm}^{2.857000}\right)^{*}$ & B & 1.250 \\
\hline $\begin{array}{l}\text { Long rough dab } \\
\text { Hippoglossoides platessoides }\end{array}$ & $\begin{array}{l}F L=-24.520+(O L \times 48.350) \\
F L=-20.830+(O W \times 59.433)\end{array}$ & $\begin{array}{l}\mathrm{H} \\
\mathrm{P}\end{array}$ & $\begin{array}{l}\mathrm{FW}=0.00400\left(\mathrm{FLcm}^{3.203900}\right) \\
\mathrm{FW}=0.00400\left(\mathrm{FLcm}^{3.203900}\right)\end{array}$ & $\mathrm{C}$ & $\begin{array}{l}1.250 \\
1.240\end{array}$ \\
\hline Witch Glyptocephalus cynoglossus & $\begin{array}{l}F L=-100.650+(O L \times 78.290) \\
F L=-272.000+(O W \times 116.000)\end{array}$ & $\stackrel{\mathrm{H}}{\mathrm{P}}$ & $\begin{array}{l}F W=0.001700\left(\mathrm{FLcm}^{3.389800}\right) \\
F W=0.001700\left(\mathrm{FLcm}^{3.389800}\right)\end{array}$ & $\begin{array}{l}\mathrm{C} \\
\mathrm{C}\end{array}$ & $\begin{array}{l}1.250 \\
1.240\end{array}$ \\
\hline LRD/witch & $\mathrm{FL}=-52.600+(\mathrm{OL} \times 61.102)^{\cdot}$ & $\mathrm{H}$ & $F W=0.125180\left(\mathrm{OL}^{4.144100}\right)^{\circ}$ & $\mathrm{H}$ & 1.250 \\
\hline Unidentifed flatfish & $\begin{array}{l}F L=-25.950+(\mathrm{OL} \times 53.274)^{\circ} \\
F L=-38.100+(\mathrm{OL} \times 76.600)^{\circ}\end{array}$ & $\stackrel{\mathrm{H}}{\mathrm{P}}$ & $\begin{array}{l}F W=0.009923\left(\mathrm{FLcm}^{3.035950}\right) \\
F W=0.009923\left(\mathrm{FLcm}^{3.035950}\right)\end{array}$ & $\begin{array}{l}\mathrm{B} / \mathrm{C} \\
\mathrm{B} / \mathrm{C}\end{array}$ & $\begin{array}{l}1.250 \\
1.240\end{array}$ \\
\hline $\begin{array}{l}\text { Sandeels Ammodytes spp. } \\
\text { and Gynamodytes spp. }\end{array}$ & $\begin{array}{l}F L=18.376+(O L \times 51.441) \\
F L=10.589+(O W \times 110.199)\end{array}$ & $\begin{array}{l}E \\
E\end{array}$ & $\begin{array}{l}F W=1.083343\left(\mathrm{OL}^{2.446703}\right) \\
F W=5.731932\left(\mathrm{OW}^{2.679693}\right)\end{array}$ & $\begin{array}{l}E \\
E\end{array}$ & $\begin{array}{l}1.160 \\
1.160\end{array}$ \\
\hline Greater sandeels Hyperoplus spp. & $F L=-4.024+(O L \times 56.840)$ & $\mathrm{H}$ & $\mathrm{FW}=1.083343\left(\mathrm{OL}^{2.446703}\right)$ & $E$ & 1.160 \\
\hline Argentines Argentina spp. & $\begin{array}{l}F L=-35.049+(O L \times 46.370) \\
F L=-50.464+(O W \times 73.583)\end{array}$ & $\begin{array}{l}E \\
E\end{array}$ & $\begin{array}{l}F W=0.082530\left(\mathrm{OL}^{3.830400}\right) \\
F W=0.140400\left(\mathrm{OW}^{4.654200}\right)\end{array}$ & $\begin{array}{l}E \\
E\end{array}$ & $\begin{array}{l}1.250 \\
1.240\end{array}$ \\
\hline Wrasses Labridae & $F L=3.320\left(\mathrm{OL}^{53.440}\right)^{*}$ & $\mathrm{H}$ & $\mathrm{FW}=2.330310\left(\mathrm{OL}^{2.934000}\right)$ & $\mathrm{H}$ & 1.250 \\
\hline Catfish Anarhichas lupus & $\mathrm{FL}=-242.270+(\mathrm{OL} \times 216.510)$ & $\mathrm{H}$ & $F W=0.003300\left(\mathrm{FLcm}^{3.249100}\right)$ & $\mathrm{C}$ & 1.250 \\
\hline Dragonet Callionymus spp. & $\begin{array}{l}F L=-51.390+(\mathrm{OL} \times 84.120) \\
F L=-68.660+(\mathrm{OW} \times 167.300)\end{array}$ & $\begin{array}{l}P \\
p\end{array}$ & $\begin{array}{l}\mathrm{FW}=0.022000\left(\mathrm{FLcm}^{2.590700}\right) \\
\mathrm{FW}=0.022000(\mathrm{FLcm} \\
2.590700\end{array}$ & $\begin{array}{l}\mathrm{C} \\
\mathrm{C}\end{array}$ & $\begin{array}{l}1.250 \\
1.240\end{array}$ \\
\hline Norway haddock Sebastes viviparus & $F L=-14.460+(\mathrm{OL} \times 38.810)$ & $\mathrm{H}$ & $\mathrm{FW}=0.000750\left(\mathrm{OL}^{5.410000}\right)$ & $\mathrm{H}$ & 1.250 \\
\hline Curled octopus Eledone & & & $\begin{array}{l}F W=5.365600\left(\mathrm{LHL}^{2.850009}\right) \\
F W=8.250720\left(\mathrm{UHL}^{2337400}\right)\end{array}$ & $\stackrel{\mathrm{Cl}}{\mathrm{P}}$ & \\
\hline Rossia Rossia macrosoma & & & $F W=8.846306\left(\mathrm{LHL}^{1.650000}\right)$ & $\mathrm{Cl}$ & \\
\hline Market squid Loligo forbesi & & & $\begin{array}{l}F W=19.105950\left(\mathrm{LRL}^{84} 274\right) \\
F W=31.092000\left(\mathrm{URL}^{2497120}\right)\end{array}$ & $\stackrel{\mathrm{Cl}}{\mathrm{P}}$ & \\
\hline Sepiolidae & & & $\begin{array}{l}F W=0.642454\left(\mathrm{UHL}^{0.350000}\right) \\
F W=1.491820\left(\mathrm{LHL}^{0.350000}\right)\end{array}$ & $\begin{array}{l}\mathrm{Cl} \\
\mathrm{Cl}\end{array}$ & \\
\hline
\end{tabular}




\section{LITERATURE CITED}

Anon (1996a) Shetland in statistics. Shetland Islands Council's Development Department, Lerwick, Shetland

Anon (1996b) Scottish sea fisheries statistical tables 1995. Scottish Office Agriculture Environment and Fisheries Department, Edinburgh

Bedford BC. Woolner LE, Jones BW (1986) Length-weight relationships for commercial fish species and conversion factors for various presentations. Fisheries Data Report. MAFF, Lowestoft

Boyle GJ (1990) The feeding ecology of common seals (Phoca vitulina L.) in Loch Linnhe, West Scotland. MSc thesis, Imperial College of Science, Technology and Medicine, University of London

Boyle PR, Pierce GJ, Diack JSW (1990) Sources of evidence for salmon in the diets of seals. Fish Res 10:137-150

Brown EG (1995) Survey and review of data on grey seal populations around Shetland. Unpublished report to Scottish Natural Heritage, Contract No. NE/S/32/94, Lerwick, Shetland

Brown EG, Pierce GJ (1997) The diet of harbour seals at Mousa, Shetland, during the third quarter of 1994. J Mar Biol Assoc UK 77:539-555

Clarke MR (ed) (1986) A handbook for the identification of cephalopod beaks. Clarendon Press, Oxford

Cottrell PE, Trites AW, Miller EH (1996) Assessing the use of hard parts in faeces to identify harbour seal prey: results of captive feeding trials. Can J Zool 74:875-880

Coull KA, Jermyn AS, Newton AW, Henderson GI, Hall WB (1989) Length-weight relationships for 88 species of fish encountered in the North East Atlantic. Scottish Fisheries Research Report 43, Aberdeen

da Silva J, Neilson JD (1985) Limitations of using otoliths recovered in scats to estimate prey consumption in seals. Can J Fish Aquat Sci 42:1439-1442

Dellinger T, Trillmich F (1988) Estimating diet composition from scat analysis of otariid seals (Otariidae): is it reliable? Can J Fish Aqquat Sci 42:1865-1870

des Clers S, Prime J (1996) Seals and fishery interactions: observations and models in the Firth of Clyde, Scotland. In: Greenstreet SPR, Tasker ML (eds) Aquatic predators and their prey. Blackwell Science, Oxford. p 124-132

Dorman. JA (1989) Some aspects of the biology of the garfish Belone belone (L.) from southern Ireland. J Fish Biol 35:621-629

Dorman JA (1991) Investigations into the biology of the garfish, Belone belone (L.) in Swedish waters. J Fish Biol 39:59-69

Duck CD, Hall AJ, Ingram SS (1993) Monitoring the impact of the M.V. Braer oil spill in Shetland: common seal aerial survey, August 1993. Unpublished report to the Ecological Steering Group on the Oil Spill in Shetland, Sea Mammal Research Unit, NERC, Cambridge

Evans SM, Hunter JE, Elizal, Wahju RI (1994) Composition and fate of the catch and by-catch in the Farne Deep (North Sea) Nephrops fishery. ICES J Mar Sci 51:155-168

Garthe S, Camphuysen CJ, Furness RW (1996) Amounts of discards by commercial fisheries and their significance as food for seabirds in the North Sea. Mar Ecol Prog Ser 136: $1-11$

Garthe S. Huppop O (1994) Distrubution of ship-following seabirds and their utilization of discards in the North Sea in summer. Mar Ecol. Prog Ser 106:1-9

Gulland JA (1987) The impact of seals on fisheries. Mar Pol (July 1987), p 196-204

Hammond PS, Hall AJ, Prime J (1994a) The diet of grey seals around Orkney and other island and mainland sites in north-eastern Scotland. J Appl Ecol 31:340-350

Hammond PS, Hall AJ, Prime J (1994b) The diet of grey seals in the Inner and Outer Hebrides. J Appl Ecol 31:737-746

Härkönen T (1986) The guide to the otoliths of the bony fishes of the north-east Atlantic. Danbiu ApS, Hellerup, Denmark

Härkönen $\Upsilon$ (1987) Seasonal and regional variations in the feeding habits of the harbour seal, Phoca vitulina, in the Skagerrak and the Kattegat. J Zool 213:535-543

Harvey JT (1989) Assessment of the errors associated with harbour seal (Phoca vitulina) faecal sampling. J Zool 219:101-111

Harvey JT, Antonelis GA (1994) Biases associated with nonlethal methods of determing the diet of northern elephant seals. Mar Mamm Sci 10:178-187

Harwood JA (1987) Competition between seals and fisheries. Sci Prog 71:429-437

Harwood JA (1992) Assessing the competitive effect of marine mammal predation on commercial fisheries. In: Payne AIL, Brink KH, Mann KH, Hilborn R (eds) Benguela trophic functioning. S Afr J Mar Sci 12:689-693

Hiby L, Duck D, Thompson D, I Jall A, Harwood J (1996) Seals stocks in Great Britain. NERC News, January 1996, Swindon

Hopkins PJ (1986) Exploited fish and shellfish populations in the Moray Firth. Proc R Soc Edinb 91B:57-72

Jobling M (1987) Marine mammal faeces samples as indicators of prey importance: a source of error in bioenergetic studies. Sarsia 72:255-260

McConnell BJ, Chambers C, Nicholas KS, Fedak MA (1992) Satellite tracking of grey seals (Halichoerus grypus). J Zool 226:271-282

Muus BJ, Dahlstrom P (1977) Guide to the sea fishes of Britain and north western Europe. Wm Collins and Sons Ltd, London.

Olsen M, Bjørge A (1995) Seasonal and regional variations in the diet of harbour seals in Norwegian waters. In: Blix AS, Walløe L, Ultang $\varnothing$ (eds) Whales, seals, fish and man. Elsevier Science BV, Amsterdam, p 271-285

Pierce GJ, Boyle PR, Diack JSW (1991a) Identification of fish otoliths and bones in faeces and digestive tracts of seals. J Zool 223:320-328

Pierce GJ, Boyle PR, Thompson PM (1990) Diet selection by seals. In: Barnes M, Gibson RN (eds) Trophic relationships in the marine environment. Proc 24th Eur Mar Biol Symp, Oban 1989. Aberdeen University Press, Aberdeen, p 222-238

Pierce GJ, Thompson PM, Miller A, Diack JSW, Miller D. Boyle PR (1991b) Seasonal variation in the diet of common seals (Phoca vitulina) in the Moray Firth area of Scotland. J Zool 223:641-652

Prime JH. Hammond PS (1.990) The diet of grey seals from the south-western North Sea assessed from the analyses of hard parts found in faeces. J Appl Ecol 27:435-447

Rae BB (1960) Seals and Scottish Fisheries. Department of Agriculture and Fisheries for Scotland Marine Research, 1960, No. 2, Edinburgh

Rae BB (1968) The food of seals in Scottish waters. Department of Agriculture and Fisheries for Scotland Marine Research, 1968, No. 2, Edinburgh

Rae BB (1973) Further observations on the food of seals. J Zool $169: 287-297$

Sergeant DE (1951) The status of the corrmon seal (Phoca vitulina L.) on the East Anglian coast. J Mar Biol Assoc UK $29: 707-717$

SMRU (1984) Interactions between grey seals and UK fish- 
eries. Report on research conducted for the Department of Agriculture and Fisheries for Scotland by the Sea Mammal Research Unit. NERC, Cambridge

SMRU (1994) Grey seals in the North Sea and their interactions with fisheries. Final report to the Ministry of Agriculture, Fisheries and Food on contract MF 0503. NERC. Cambridge

Thompson PM (1993) Harbour seal movement patterns. Symp Zooì Soc Lond 66:225-239

Thompson PM, Miller D (1990) Summer foraging activity and movements of radio-tagged common seals (Phoca vitulina L.) in the Moray Firth, Scotland. J Appl Ecol 27:492-501

Tollit DJ, Thompson PM (1996) Seasonal and between year

Editorial responsibility: Otto Kinne (Editor),

Oldendorf/Luhe, Germany variations in the diet of harbour seals in the Moray Firth Scotland. Can J Zool 74:1110-1121

Tollit DJ, Steward M, Thompson PM, Pierce GJ, Santos MB, Hughes S (1997) Species and size differences in the digestion of otoliths and beaks; implications for estimates of pinniped diet composition. Can J Fish Aquat Sci 54: 105-119

Watt J, Pierce GJ, Boyle PR (1997) A gurde to the identification of North Sea fish using premaxillae and vertebrae. Co-operative Research Report No. 220, International Council for the Exploration of the Sea, Copenhagen

Wheeler A (1978) Key to the fishes of Northern Europe. Frederick Warne Ltd, London

Submitted: September 23, 1997; Accepted: March 17, 1998 Proofs received from author(s): May 22, 1998 